\section{Physicochemical, Sensory Char- acteristics and Cost of Production of Soy Milk Cheese, Sudanese White Cheese and Their Mixture During Storage}

\section{Elmahi AKH and Ibtisam EM El Zubeir*}

Department of Dairy Production, Faculty of Animal Production, University of Khartoum, Sudan

\begin{abstract}
This study was designed to produce soymilk cheese (tofu) and to compare its properties to that of Sudanese white cheese using cow's milk and mixture cheese (50\% soymilk and $50 \%$ cow's milk). The chemical composition (fat, protein, total solids, ash and titratable acidity) and sensory characteristics (color, taste, texture, saltiness and overall acceptability) were determined at 1, 5, 10 and 15 days of storage. The results showed that fat, total solids and ash content and the titratable acidity were significantly $(P<0.001)$ high in Sudanese white cheese, while protein content was significantly $(P<0.001)$ higher in the mixture cheese. The storage period significantly affected fat, protein, total solids, ash content and acidity in all cheeses. The color, taste and overall acceptability of cheeses were significantly $(P<0.05)$ varied due to the presence of soymilk, while saltines and texture of different cheeses were not affected. The saltines, texture and overall acceptability were significantly affected during the storage period, while color and taste were not affected. The high cost of production was recorded for Sudanese white cheese, while tofu cheese revealed the lowest cost. Hence this study concluded the soybeans is good source of high-quality protein and that can be utilized in dairy products, also it is important encourage growing soybean in Sudan in order to utilize it as milk substitute. However more researches are needed to evaluate the microbiological, quality and flavor of tofu cheese.
\end{abstract}

Keywords: Chemical composition; Mixture cheese; Production cost; Sensory properties; Soymilk; Storage; Sudanese white cheese; Tofu cheese

*Corresponding author: Ibtisam EM El Zubeir, Department of Dairy Production, Faculty of Animal Production, University of Khartoum, P. O. Box 321 Khartoum, Sudan, Tel:+249 912251610; E-mail: Ibtisamelzubeir17@gmail.com

Citation: Elmahi AKH, Ibtisam EM El Zubeir (2020) Physicochemical, Sensory Characteristics and Cost of Production of Soy milk Cheese, Sudanese White Cheese and Their Mixture During Storage. J Protein Res Bioinform 2: 007.

Received: April 05, 2020; Accepted: April 13, 2020; Published: April 22, 2020

Copyright: ( 2020 Elmahi AKH, et al. This is an open-access article distributed under the terms of the Creative Commons Attribution License, which permits unrestricted use, distribution, and reproduction in any medium, provided the original author and source are credited.

\section{Introduction}

Soybean (Glycine max L) is a leguminous plant, which is rich source of good quality protein; besides nutritional benefits soybeans provide several therapeutic benefits as soybeans protein provides all the essential amino acids in the amounts needed for human health [1]. The health benefits of soy protein have been documented. In addition, soy products offer a considerable appeal for a growing segment of consumers with certain dietary and health concerns [2]. Moreover, soymilk is rich in high quality proteins and suitable for the growth of bifidobacteria [3].

Tofu is a typical soybean curd product that is prepared through coagulation of soybean protein with addition of calcium and magnesium salt and/or gluconolactones [4]. Tofu is made by soaking soybeans in water, wet-milling, removal of soy fiber (named okara) by filtration, cooking and coagulation of the soy protein by the addition of calcium salts. The precipitated protein is collected, and pressed to firm consistency and is cooked prior to consumption [5]. Tofu is very much a customary part of the Malaysian diet [6]. Tofuyo and sufu are fermented tofu products which are popular in Okinawa, Japan and in China, respectively [7].

Various coagulants have been used in the preparation of tofu, each coagulant resulting in a product with textural characteristics varying from soft to firm and with moisture content ranging from 70 to $90 \%$ [8]. In northern part of Nigeria, tofu; a coagulated product of soybean milk; is usually produced at household level using various types of coagulants such as calcium salt, magnesium salt, alum and steep water (effluent from pap produced from maize) [9].

The factors that affecting yield, quality and texture of tofu include variety of soybeans and storage conditions, time and temperature of soaking the soybeans, extent of heat-treatment of soymilk, type and concentration of coagulant and rate of stirring and coagulation temperature [6]. Nutritional value per $100 \mathrm{~g}$ is $291 \mathrm{~kJ}$ (70 kal) energy, 1.5 $\mathrm{g}$ carbohydrates, $3.5 \mathrm{~g}$ fat, $0.5 \mathrm{~g}$ saturated fatty acids, $8 \mathrm{~g}$ protein, 130 $\mathrm{mg}$ calcium, $1.10 \mathrm{mg}$ iron and $4 \mathrm{mg}$ sodium [10].

In Sudan, Sudanese white cheese (Gibna bayda) is the major type of cheese that is produced traditionally with slight variations among the producers [11-13]. However, the traditional methods of processing Sudanese white cheese need to be encouraged and improved to utilize the surplus milk in rural areas [14]. Tofu cheese was not produced in Sudan regardless of the huge quantities of legumes cultivation and utilization. The objectives of this study are to produce cheese using different percentages of soymilk (tofu cheese and mixture cheese) and to compare its chemical and sensory characteristics to that of Sudanese white cheese using cow's milk. It is also meant to estimate the cost of production of different produced cheeses.

\section{Materials and Methods}

\section{Source of milk, soybean and coagulants}

Cow's milk was obtained from Khartoum University Farm, while rennet powder (one gram per 50 liters of milk) was purchased from a 
private Veterinary Services Center in Khartoum North. The salt and lemon were brought from the local market. Soybeans were obtained from Al-hideba Research Station, Ad-Damir- Nile State, Sudan.

\section{Preparation of soymilk and tofu cheese}

Soymilk and tofu was prepared according to the method of Lim [15] with some modifications as follows: Beans were soaked in tap water overnight and blended using high speed blender for 3 minutes, the resultant slurry was passed through filter cloth then cooked for 1520 minutes (one cup soaked beans require 3 cups water). The soymilk (3 liters) was heated till boiling point, and then the salt (60 grams) and lemon juice $(75 \mathrm{ml})$ were added and stirred. The mixture was then left to stand for 5-10 minutes, the curd was separated to skim out the curd and poured in a cheese mold with cheese cloth, it was pressed down using a heavy object $(3 \mathrm{Kg})$ and let for 45 minutes then the tofu was ready for use. About one and half pounds of tofu should be made by 1-liter soymilk. Before used, tofu cheese was cooked with oil and garlic.

\section{Sudanese white cheese manufacturing}

Sudanese white cheese was manufactured as was described previously [12].

\section{Mixture cheese processing}

One liter of cow's milk was mixed with one liter of soymilk, the mixture was heated to $72{ }^{\circ} \mathrm{C}$ then the salt (60 grams) and lemon juice $(75 \mathrm{ml})$ were added and the milk was stirred for 3-5 minutes and then left to curd. The curd was then transferred into clean wooden molds with cheese' cloth, it was pressed down using heavy object and left for 45 minutes to drain the whey. Then the curd was cut and placed in a refrigerator $\left(7^{\circ} \mathrm{C}\right)$ for analysis $(15$ days $)$.

\section{Cheese analysis}

Fat content was determination by Gerber method, the protein content was determined by Kjeldhal method and the ash content was determined according to the modified method of AOAC [16]. Also, the titraitble acidity was determined according to AOAC [16]

\section{Sensory evaluation}

A panel of 10 untrained panelists; however they are familiar with Sudanese white cheese, were chosen and asked to evaluate cheese (color, flavor, body, taste, saltiness and over all acceptability) using an evaluation sheet where color ranged from $1=$ not acceptable to $4=$ acceptable, taste $1=$ absent to $4=$ excessively acid, body $1=$ pasty to $4=$ smooth, saltiness $1=$ moderate to $4=$ too salted and the overall acceptability $1=$ not acceptable to $4=$ acceptable.

\section{Cost of production}

The cost of production of cheeses under study was: 1 liter of cow's milk cost $8 \mathrm{SD}$ at the time of experiment, while the price of $1 \mathrm{~kg}$ of soybean was $8.6 \mathrm{SD}$. To manufacture $1 \mathrm{~kg}$ of white cheese requires 5-6 liters of milk. One liter of soymilk prepared by 200 grams of dried soybean, to manufacture $1 \mathrm{~kg}$ of tofu cheese it requires 3 liters of soymilk.

\section{Statistical analysis}

The data of the present study was analyzed using Statistical Package for Social Studies Software "SPSS" version 11.5. ANOVA was performed to evaluate the significance of the levels of soymilk and storage period on physicochemical and sensory characteristics of the different cheeses. Differences among means were separated by Duncan's Multiple Range test. The threshold for significance was $\mathrm{P}<0.05$.

\section{Results and Discussion}

\section{Effect of soymilk level on physicochemical characteristics of cheeses}

Table 1 presents the chemical composition of different types of cheese under study. The total solids content was significantly $(\mathrm{P}<0.001)$ higher in Sudanese white cheese $(50.17 \%)$ compared to mixture cheese $(47.91 \%)$ and tofu cheese $(46.44 \%)$. Similarly, the means of total solids content were $48.14 \pm 7.09 \%$ and $45.76 \pm 8.27 \%$ for traditionally and modern produced Sudanese white cheese samples, respectively [13]. On the other hand, the moisture content of alum-coagulated tofu of $5.50 \pm 1.17 \%$ compared to tofu that coagulated using steep water $(4.8 \pm 1.10 \%)$, magnesium chloride $(4.3 \pm 1.04 \%)$ and calcium chloride $(3.7 \pm 0.96 \%)$ were reported [17]

\begin{tabular}{|c|c|c|c|c|c|}
\hline \multirow{2}{*}{ Cheese type } & \multicolumn{5}{|c|}{ Parameters } \\
\cline { 2 - 6 } & Fat (\%) & Protein (\%) & Total solids (\%) & Ash (\%) & Acidity (\%) \\
\hline White cheese & $29.64^{\mathrm{a}}$ & $16.35^{\mathrm{b}}$ & $50.17^{\mathrm{a}}$ & $3.23^{\mathrm{a}}$ & $0.56^{\mathrm{a}}$ \\
\hline Mixture cheese & $16.02^{\mathrm{b}}$ & $24.06^{\mathrm{a}}$ & $47.91^{\mathrm{b}}$ & $1.37^{\mathrm{b}}$ & $0.12^{\mathrm{c}}$ \\
\hline Tofu cheese & $10.47^{\mathrm{c}}$ & $18.64^{\mathrm{b}}$ & $46.44^{\mathrm{b}}$ & $1.05^{\mathrm{b}}$ & $0.04^{\mathrm{b}}$ \\
\hline SE & 0.69 & 1.8 & 1.3 & 1.9 & 0.008 \\
\hline LS & $* * *$ & $* * *$ & $* * *$ & $* * *$ & $* * *$ \\
\hline
\end{tabular}

Table 1: Comparison of physicochemical characteristics of white cheese, tofu cheese and their mixture cheese.

Means with the same letters in the same column were not significantly different $* * *=\mathrm{P}<0.001$

$\mathrm{SE}=$ Stander Erro

$\mathrm{LS}=$ level of significant

The fat content was significantly $(\mathrm{P}<0.001)$ affected by the presence of soymilk being high in Sudanese white cheese (29.64\%) followed by mixture cheese (16.02\%) compared to tofu cheese $(10.47 \%)$. This indicates the health benefits as the less fat that would reduce the risk of obesity. However lower values for the fat content of Sudanese white cheese samples from traditional $(21.10 \pm 2.31 \%)$ and modern processing (22.35 $\pm 3.13 \%$ ) was reported [13]. Fat value of $20.84 \%$ for Sudanese white cheese produced at household level in Dueim area was also found [18]. Sudanese white soft cheese should contain in average fat content of $20 \%$ as maximum [19]. The high average fat content in this study for Sudanese white cheese might be due to high fat content of raw milk as the local cows are significantly capable for producing higher milk fat throughout their lactations [20]. The milk with different fat percent for cheese making showed significant differences $(\mathrm{P}<0.05)$ on the total solids, ash and fat contents of cheese [21]. The fat levels of milk showed significant differences $(\mathrm{P}<0.05)$ in content of total solids, protein, fat, ash, acidity and total volatile fatty acids of Sudanese white cheese [22]. However higher fat content was reported for tofu compared to this study. The calcium coagulated tofu recorded high value of fat content $(35.2 \pm 2.97 \%)$, followed by alum $(32.80 \pm 2.86 \%)$, steep water $(31.5 \pm 2.81 \%)$ coagulated tofu compared to $\mathrm{MgCl}(18.70 \pm 2.16 \%)$ coagulated tofu [23] .

The protein content was significantly $(\mathrm{P}<0.001)$ higher in the mixture cheese $(24.06 \%)$ and lower in Sudanese white cheese (16.35\%). 
Tofi cheese revealed protein value of $18.64 \%$. Similarly ranges of $13.3-17.6 \%$ [9] and 56.89-59.98\% [17] were reported previously for the protein content of tofu. Also the values of proteins in tofu cheese obtained during the present study are lower than the values found in Nigeria that showed steep water coagulated tofu recorded high protein value $(39.0 \pm 3.12 \%)$, followed by $\mathrm{MgCl}(37.20 \pm 3.05 \%), \mathrm{CaCl}$ coagulated tofu $(36.6 \pm 3.02 \%)$ compared to alum coagulated tofu $(32.1 \pm 2.83 \%)$ [23]. The variations in protein contents of tofu could be because of soybean variety used and the processing method adopted [23]. Moreover, for most Nigerians, tofu is receiving attention because it is high in protein and its usage as a substitute for meat [23].

The protein content of Sudanese white cheese was found to range from 14.3 to $32.8 \%$. This finding agreed with those of $15.9 \%$ protein content for Sudanese white cheese [24]. The protein content value of $13.07 \pm 2.17 \%$ with a range of 7.7 to $17.2 \%$ for traditional cheese and value of $15.36 \pm 6.83 \%$ with a range of 7.1 to $29.1 \%$ were reported for modern produced cheese [13]. The average protein content per dry matter weight of white soft cheese estimated to be $15 \%$ (a lowest limit) $15-20 \%$ and $20-35 \%$ as given by Sudanese Standards [19].

The ash content was significantly $(\mathrm{P}<0.001)$ affected by the presence of soymilk with highest value being in Sudanese white cheese $(3.23 \%)$ and low both in the mixture cheese $(1.37 \%)$ and tofu cheese $(1.053 \%)$. The results of ash content of Sudanese white cheese were within the range that reported an average ash content of $6.2 \%$ for $\mathrm{Su}-$ danese white cheese [24]. The ash is estimated to be $5 \%$ as a lowest value [19], The mean of ash for Sudanese white cheese produced by traditional producers was $9.58 \pm 3.14 \%(3.8-15.6 \%)$ and $5.73 \pm 3.47 \%$ $(3.0-13.5 \%)$ for Sudanese white cheese from modern producers [13]. The Sudanese white cheese with the different fat levels were significantly $(\mathrm{P}<0.05)$ different in salt, sodium, calcium and phosphorous [25]. The difference in ash content might be due to the different levels of salt used [12,14,26,27].

The ash content of tofu and mixture cheeses obtained during the present study (Table 1) were lower than those reported $5.80-8.80 \%$ [28] and 5.64-5.76\%, respectively [17] for ash content of tofu. Similarly, higher ash content of tofu coagulated with alum, steep water, magnesium chloride and calcium chloride $(3.41 \pm 0.92 \%, 3.6 \pm 0.95 \%$, $3.4 \pm 0.92 \%$ and $3.3 \pm 1.82 \%$, respectively) were reported [23]. The differences might be due to variations of processing procedure as well as soybean varieties processed [23].

The titratable acidity of cheeses was significantly $(\mathrm{P}<0.001)$ high in Sudanese white cheese $(0.56 \%)$ followed by the mixture cheese $(0.12 \%)$ compared to tofu cheese $(0.04 \%)$. The average acidity of cheese samples was $1.08 \%$ with a range changing from $0.36 \%$ to $1.80 \%$ [11]. Similarly, significant $(\mathrm{P} \leq 0.05)$ differences in the acidity of Sudanese white cheese samples that was produced by traditional and modern processing was reported [13]. The increase in the acidity is due to increase in lactic acid by the action of lactic acid bacteria present in the raw milk $[29,30]$.

\section{Effect of storage period on the physicochemical character- istics of cheeses}

Table 2 presents the chemical composition of cheeses during the storage period. The total solids content increased from $47.1 \%$ at day 1 to $48.9 \%$ at day 10 then decreased at the end of storage period although there were no significant differences. The results of total solids content might be due to diffusion of water into the whey leading to increase in the solids content of the cheese. These results are in accordance with those reported previously [29,31]. Data showed that the fat content was increased in day 10 then decreased to the end of storage period with no significant differences (Table 2). The result of fat content is in agreement with the findings reported previously $[22,29,32]$. Similarly, a decrease in the fat content during storage period of cheese was reported [30]. However, it contradicted with those reported previously [31]. The protein content increased from $19.49 \%$ to $20.11 \%$ at day 5 , and then decreased at the end of the storage period with non significant variation (Table 2). Decreasing of protein content is in agreement with results that reported a decrease in the protein content during ripening of white brined cheese [30,33]. Moreover, the protein content of Sudanese white cheese was affected significantly $(\mathrm{P} \leq 0.05)$ by storage containers and storage period as the maximum levels of the protein content were obtained at the beginning of the storage period [22]. On the other hand, it was concluded that storage in plastic containers would lead to significant losses in protein and keeping the Sudanese white soft cheese in tin containers would conserve its nutritive value during the long storage [34]. This could be attributed to the breakdown of casein and utilization of proteolytic products by microorganisms during ripening $[31,33,35]$. However, the results are not in line with the findings of El Owni and Hamid [29]. The ash content of cheese was not significantly affected by storage period, it decreased from $2.27 \%$ at day 1 to $1.56 \%$ at day 15 (Table 2). The result of ash content was in disagreement with the finding that showed increasing ash content during storage period. The increase in ash content during pickling may be due to the decrease in moisture content and absorption of salt by the curd [29].

\begin{tabular}{|c|c|c|c|c|c|}
\hline \multirow{2}{*}{ Storage period } & \multicolumn{5}{|c|}{ Parameters } \\
\cline { 2 - 6 } & Fat (\%) & Protein (\%) & T.S (\%) & Ash (\%) & Acidity (\%) \\
\hline Day 1 & $17.61^{\mathrm{a}}$ & $19.49^{\mathrm{a}}$ & $47.1^{\mathrm{a}}$ & $2.27^{\mathrm{a}}$ & $0.14^{\mathrm{b}}$ \\
\hline Day 5 & $17.81^{\mathrm{a}}$ & $20.11^{\mathrm{a}}$ & $48.6^{\mathrm{a}}$ & $2.05^{\mathrm{ab}}$ & $0.27^{\mathrm{a}}$ \\
\hline Day 10 & $21.42^{\mathrm{a}}$ & $19.92^{\mathrm{a}}$ & $48.9^{\mathrm{a}}$ & $1.66 \mathrm{a}^{\mathrm{b}}$ & $0.27^{\mathrm{a}}$ \\
\hline Day 15 & $18.0^{\mathrm{a}}$ & $19.21^{\mathrm{a}}$ & $48.0^{\mathrm{a}}$ & $1.56^{\mathrm{b}}$ & $0.29^{\mathrm{a}}$ \\
\hline SE & 0.691 & 1.81 & 1.32 & 0.11 & 0.008 \\
\hline L.S & NS & NS & NS & NS & $* * *$ \\
\hline
\end{tabular}

Table 2: Effect of storage period on physicochemical characteristics of cheeses.

$* * *=\mathrm{p}<0.00$

NS $=$ Not significant

$\mathrm{SE}=$ Standard Error

$\mathrm{LS}=$ level of significance

The titratable acidity was significantly $(\mathrm{P}<0.001)$ affected by storage period as it increased to $0.28 \%$ at the end of storage period (Table 2 ). The increasing in acidity was reported previously [32]. It was also observed that the maximum levels of the acidity were obtained at the end of storage [22]. The high acidity of raw milk cheese could be due to the fact that storage temperature activated the natural microflora of raw milk and resulted in the development of acidity as the result of lactose fermentation [27].

\section{Effect of soymilk level and storage period on the chemical composition of cheese}

Table 3 presents the effect of soymilk levels and storage period on the chemical composition of cheeses. Total solids content increased to the end of storage period in the Sudanese white cheese and fluctuated 
in mixture and tofu cheese. The variation could be due to the quality and composition of the cheese, which may vary considerably due to factors such as the quality and composition of the clotted milk, the method of manufacture, the time required to complete the whey drain, the quality of salt added and the method of handling of the finished cheese [36]. Also, various factors such as variety of seeds, processing conditions, seed storage, stability of soybean composition, type of coagulants has been reported to affect qualities of soybean curd [37]. Fat content increased to day 10 then decrease at the end of storage period. On the other hand, the action of lipolytic enzymes may be the possible reason behind the decline of fat content. The results of fat content contradicted with those which reported a decrease in fat content as a result of increased solubility of protein results in decrease in hardness of tofu [38].

\begin{tabular}{|c|c|c|c|c|c|c|}
\hline $\begin{array}{c}\text { Soymilk } \\
\text { level }\end{array}$ & $\begin{array}{c}\text { Storage } \\
\text { period }\end{array}$ & Fat (\%) & $\begin{array}{c}\text { Protein } \\
\mathbf{( \% )}\end{array}$ & $\begin{array}{c}\text { Total solids } \\
\mathbf{( \% )}\end{array}$ & $\begin{array}{c}\text { Ash } \\
\mathbf{( \% )}\end{array}$ & $\begin{array}{c}\text { Acidity } \\
\mathbf{( \% )}\end{array}$ \\
\hline \multirow{4}{*}{$\begin{array}{c}\text { White } \\
\text { cheese }\end{array}$} & 1 & 27.21 & 16.96 & 49.36 & 3.85 & 0.24 \\
\cline { 2 - 7 } & 5 & 26.85 & 15.85 & 49.63 & 3.40 & 0.64 \\
\cline { 2 - 7 } & 10 & 33.93 & 16.75 & 51.18 & 2.95 & 0.66 \\
\hline \multirow{4}{*}{$\begin{array}{c}\text { Mixture } \\
\text { cheese }\end{array}$} & 15 & 30.58 & 15.86 & 50.52 & 2.73 & 0.71 \\
\cline { 2 - 7 } & 1 & 14.93 & 22.88 & 46.82 & 1.43 & 0.12 \\
\cline { 2 - 7 } & 10 & 16.75 & 25.78 & 48.10 & 1.42 & 0.15 \\
\hline \multirow{4}{*}{ Tofu cheese } & 1 & 14.28 & 24.61 & 50.07 & 1.31 & 0.11 \\
\cline { 2 - 7 } & 10 & 10.66 & 18.63 & 45.49 & 1.53 & 0.05 \\
\cline { 2 - 7 } & 15 & 9.33 & 18.81 & 46.75 & 0.62 & 0.04 \\
\hline
\end{tabular}

Table 3: The effect of soymilk levels and storage period on physicochemical characteristics of different cheeses.

The protein content fluctuated in all treatment (Table 3). The results of protein content were not found to comply with that of Obtolu [39]. This might be due to difference variety of soybean, type of coagulant and the amount of coagulant used. However, the high protein content of soybeans makes it useful in combating protein-energy malnutrition, especially in the rural communities of developing countries. This is expected, as soybean is notable to contain significant amount of protein that is of high biological value with excellent essential amino acids composition comparable to animal protein except for methionine [23]. Moreover, the quality of protein in tofu has made it to be incorporated as animal-protein substitute in vegetarian diets [17].

Ash content was decreased at the end of storage period in all treatments (Table 3). The results of ash content agreed with finding which reported a decrease in total ash content of mungbean for 24 and 48 hours germination [38]. Titratable acidity increased to the end of storage period in Sudanese white cheese. The result of titratable acidity of tofu cheese (Table 3 ) is dependent on the coagulant type [38].

\section{Effect of soymilk levels on sensory characteristics of cheeses}

Table 4 showed the main effect of different levels of soymilk on the sensory characteristics of the cheeses. There were significant $(\mathrm{P}<0.05)$ differences due to the soymilk level on the color, taste and overall acceptability of the cheeses, while there were no significant $(\mathrm{P}>0.05)$ differences on the saltines, and texture of the cheeses.
This might be because calcium sulphate and gluconolactone are traditionally used as coagulants in tofu manufacture, resulting in tofu of uniform texture with high moisture content [6]. Also, it was reported that tofu coagulated with calcium salt was rated superior in terms of colour (8.0), texture (8.25), taste/ flavor (8.50) and overall acceptability (8.24) compared to the tofu obtained using citrus juices [40]. Moreover, the temperature of processing and water to bean ratio have also influenced textural qualities of tofu [37]. The tofu curds are allowed to cool and become firm and the finished tofu can then be cut into pieces, flavoring or further processed [41].

\begin{tabular}{|c|c|c|c|c|c|}
\hline \multirow{2}{*}{ Type of cheese } & \multicolumn{5}{|c|}{ Parameters } \\
\cline { 2 - 6 } & Color & Taste & Texture & Saltines & Overall Acceptability \\
\hline White cheese & 3.73 & 1.67 & 1.57 & 1.66 & 3.25 \\
\hline Mixture cheese & 3.36 & 1.45 & 1.63 & 1.64 & 3.04 \\
\hline Tofu cheese & 3.45 & 1.56 & 1.52 & 1.62 & 3.06 \\
\hline
\end{tabular}

Table 4: Effect of soymilk level on sensory characteristics of White cheese, Tofu and their mixture cheese.

The results showed that there was significant $(\mathrm{P}<0.001)$ differences in color as the best score of the color (3.73) was recorded for the Sudanese white cheese, while the lowest (3.36) was recorded in the cheese with $50 \%$ soymilk (Table 4 ). Although it was reported that tofu of good quality is generally white or light-yellow in color [6].

The best score for taste (1.67) was reported for the Sudanese white cheese, while the lowest (1.45) was found in the cheese with $50 \%$ soymilk. The Sudanese white cheese recorded the highest saltines score (1.66), while the soy cheese recorded the lowest score (1.62). The Sudanese white cheese revealed the highest acceptability than the other cheeses (100\% and 50\% soymilk) as shown in Table 4 . The level of fat content affected the Sudanese cheese acceptability and properties as the cheese made from milk with $2 \%$ fat showed the superior scores compared to that made from milk with $1 \%$ fat [25]. On the other hand, the steep water coagulated tofu had low general acceptability $(4.1 \pm 1.01 \%)$, while the tofu produced by alum, magnesium and calcium salts had very good general acceptability $(6.3 \pm 1.25$ and $6.5 \pm 1.27 \%$, respectively) [23]. However, it was found that the lemon juice coagulated tofu was more preferred in terms of flavor, mouthfeel and overall acceptability [39]. It was concluded that the tofu with steep water appears promising nutritionally if the sensory quality is improved upon as it received very low general acceptability, regardless of its high protein content [23].

\section{The effect of storage period on sensory characteristics of cheeses}

Table 5 presented the effect of storage period ( 15 days) on sensory characteristics of different cheeses. The results indicated that there were significant $(\mathrm{P}<0.05)$ changes during the storage period on the scores for texture, saltiness, and over all acceptability). The overall acceptability was affected by the storage period and decreasing toward the end of storage (Table 5). Similarly, it was found that the sensory evaluation scores for all types of Mudaffara cheese showed decreasing values during the storage period [42].

Color and taste scores were not affected by storage period, while the saltiness score showed decreased values (Table 5). The findings 
Citation: Elmahi AKH, Ibtisam EM El Zubeir (2020) Physicochemical, Sensory Characteristics and Cost of Production of Soy milk Cheese, Sudanese White Cheese and Their Mixture During Storage. J Protein Res Bioinform 2: 007.

of this study are in agreement with those reported that color score of Sudanese white cheese did not significantly change during storage period [31]. The finding also supported those reported that the saltiness was significantly different among Sudanese white cheese samples [43]. However, the findings disagreed with those reported that there was significant change in color, flavor and texture of Sudanese white cheese during the storage [29]. Similarly, it was reported that the scores for color, taste, flavor, texture and saltiness of the processed cheese showed noticeable changes during storage period [44]. On the other hand, it is very difficult to produce long-life tofu, since the smooth and fragile texture of tofu is easily destroyed by retort sterilization [4]. However, the addition of MTGase enabled not only the maintenance of the smooth texture of retorted tofu for long periods, but also increased its gel strength [45] Moreover the contemporary tofu manufacturing may choose to use one or more of the coagulants, since each play a role in producing a desired texture in the finish tofu [46].

\begin{tabular}{|c|c|c|c|c|c|}
\hline \multirow{2}{*}{ Storage period } & \multicolumn{5}{|c|}{ Parameters } \\
\cline { 2 - 6 } & Color & Taste & Saltiness & Texture & Overall acceptability \\
\hline Day1 & $3.45^{\mathrm{a}}$ & $1.57^{\mathrm{a}}$ & $1.6^{\mathrm{a}}$ & $1.51^{\mathrm{a}}$ & $2.88^{\mathrm{b}}$ \\
\hline Day 5 & $3.62^{\mathrm{a}}$ & $1.60^{\mathrm{a}}$ & $1.37^{\mathrm{a}}$ & $1.60^{\mathrm{a}}$ & $3.31^{\mathrm{a}}$ \\
\hline Day 10 & $3.53^{\mathrm{a}}$ & $1.73^{\mathrm{a}}$ & $1.57^{\mathrm{a}}$ & $1.57^{\mathrm{a}}$ & $3.18^{\mathrm{ab}}$ \\
\hline Day 15 & $3.4^{\mathrm{a}}$ & $1.87^{\mathrm{a}}$ & $1.52^{\mathrm{a}}$ & $2^{\mathrm{a}}$ & $3.92^{\mathrm{b}}$ \\
\hline SE & 0.04 & 0.04 & 0.034 & 0.044 & 0.058 \\
\hline
\end{tabular}

Table 5: Effect of storage period on sensory characteristics of white cheese and Tofu cheese and mixture cheese.

Within same letters in the same column were not significantly different $*=\mathrm{P}<0.05$

$\mathrm{NS}=$ not significant

$\mathrm{SE}=$ Standard Error

$\mathrm{LS}=$ level of significance

\section{Effect of soymilk level and storage period on sensory characteristics of cheese}

Table 6 presents the effect of soymilk level and storage period on sensory characteristics of cheese. The color score decreased at the end of storage period in Sudanese white cheese and tofu cheese and fluctuated in mixture cheese. The results of tofu acceptability may be due to the cooking of the cheese done during this study. The taste improved during storage period of Sudanese white cheese and tofu cheese.

Saltines increased in white cheese and decrease in tofu cheese. The texture score fluctuated in all types of cheeses. Overall acceptability decreased towards the end of storage period in mixture cheese and tofu cheese, and increased in Sudanese white cheese. The microstructure of tofu is responsible for texture and depends on tofu composition and manufacturing processes [47].

\section{Comparison of production cost of studied types of cheese}

Table 7 showed that the low cost of production in tofu cheese (7.86 SDG) and the highest value was found in Sudanese white cheese production (31.7 SDG). The results refer to the price of cow's milk, which is high, while the soymilk is cheap. The data also showed that the cheese making is profitable since benefit cost ratio is more than one, and the gross margin profit is equal 9.3 (positive value), which indicated the financial profitability of cheese manufacturing. It was reported that consumers in western countries consume soymilk mainly as an important replacer of cow milk due to lactose intolerance or allergic reaction to cow's milk and as a low-cost source of good quality protein and energy [2]. Moreover, the soy constituents' benefits mostly related to the reduction of cholesterol levels and menopause symptoms and the reduction of the risk for several chronic diseases such as cancer, heart disease and osteoporosis [2]. Also, it was reported that tofu is very rich in protein, fat and carbohydrate, which are energy- producing macromolecules [9].

\begin{tabular}{|c|c|c|c|c|c|c|}
\hline $\begin{array}{c}\text { Soymilk } \\
\text { level }\end{array}$ & $\begin{array}{c}\text { Storage } \\
\text { period }\end{array}$ & Color & Taste & saltiness & Texture & $\begin{array}{c}\text { Overall } \\
\text { acceptability }\end{array}$ \\
\hline \multirow{4}{*}{$\begin{array}{l}\text { White } \\
\text { cheese }\end{array}$} & 1 & 3.67 & 1.43 & 1.47 & 1.10 & 2.97 \\
\hline & 5 & 3.87 & 1.57 & 1.40 & 1.60 & 3.43 \\
\hline & 10 & 3.80 & 1.83 & 1.73 & 1.57 & 3.6 \\
\hline & 15 & 3.60 & 1.80 & 1.70 & 2 & 3.07 \\
\hline \multirow{4}{*}{$\begin{array}{l}\text { Mixture } \\
\text { cheese }\end{array}$} & 1 & 3.07 & 1.80 & 1.83 & 2.1 & 2.87 \\
\hline & 5 & 3.50 & 1.43 & 1.30 & 1.20 & 2.97 \\
\hline & 10 & 3.40 & 1.80 & 1.67 & 1.53 & 3.3 \\
\hline & 15 & 3.47 & 1.53 & 1.43 & 1.70 & 3.03 \\
\hline \multirow{4}{*}{ Tofu cheese } & 1 & 3.63 & 1.47 & 1.50 & 1.33 & 2.8 \\
\hline & 5 & 3.50 & 1.80 & 1.40 & 1.33 & 3.53 \\
\hline & 10 & 3.40 & 1.57 & 1.30 & 1.97 & 3.23 \\
\hline & 15 & 3.30 & 1.67 & 1.43 & 1.43 & 2.67 \\
\hline
\end{tabular}

\section{Conclusion}

The present study concluded that there were significant variations in the chemical composition and sensory characteristics of cheeses, which were manufactured from soymilk and cow milk and their mixture.

\begin{tabular}{|c|c|c|c|c|c|c|c|c|c|}
\hline Type of cheese & $\begin{array}{l}\text { Amount of } \\
\text { milk (liter) }\end{array}$ & $\begin{array}{l}\text { Price of } 1 \\
\text { liter }\end{array}$ & Salt (SD) & Rennet (SD) & $\begin{array}{l}\text { Lemon juice } \\
\text { (SD) }\end{array}$ & $\begin{array}{l}\text { Plastic container } \\
\text { (SD) }\end{array}$ & $\begin{array}{c}\text { Total production } \\
\text { cost }\end{array}$ & $\begin{array}{c}\text { Expected } \\
\text { revenue }\end{array}$ & $\begin{array}{c}\text { Gross margin } \\
\text { profit }\end{array}$ \\
\hline White cheese & 5 & 6 & 0.3 & 0.2 & - & 1.5 & 31.7 & 40 & 9.3 \\
\hline Tofu cheese & 3 & 1.72 & 0.2 & - & 1 & 1.5 & 7.86 & 20 & 12.14 \\
\hline Mixture cheese & 4 & 3.86 & 0.25 & - & 1 & 1.5 & 18.19 & 25 & 6.81 \\
\hline
\end{tabular}

Table 7: Comparison of production cost $1 \mathrm{Kg}$ of white cheese, Tofu cheese and their mixture.

$1 /$ Benefit cost ratio $=$ Total revenue $\backslash$ Total operation cost $=40 \backslash 31.7=1.26$

$20 \backslash 7.86=2.54$

$25 \backslash 18.19=1.43$

$2 /$ Gross margin profit $=$ Total revenue - Total operation cost 
Citation: Elmahi AKH, Ibtisam EM El Zubeir (2020) Physicochemical, Sensory Characteristics and Cost of Production of Soy milk Cheese, Sudanese White Cheese and Their Mixture During Storage. J Protein Res Bioinform 2: 007.

Significantly higher protein content was recorded in the cheese manufacture from mixture soymilk and cow milk. The overall acceptability was increased at day 10 then decreased in all types of cheeses. The cheese manufactured from soymilk was of low cost and acceptable. Hence it was recommended that soybean is a good source of high-quality protein that should be encouraged to be grown in Sudan and utilizing it as milk and meat substituted due to its health benefits.

\section{References}

1. Fan MZ, Sauer WC, Lange CFM (1995) Amino acid digestibility in soybean meal, extruded soyabean and full-fat canola for early-weaned pigs. Animal Feed Science Technology 52: 189-203.

2. Jooyandeh H (2011) Soy products as healthy and functional foods. Middle-East Journal of Scientific Research 7: 71-80.

3. Shimakawa Y, Matsubara S, Yuki N, Ikeda M, Ishikawa F (2003) Evaluation of Bifidobacterium breve strain Yakult-fermented soymilk as a probiotic food Int. J Food Microbiol 81: 131-136.

4. Motok M, Kumazawa IY (2000) Recent research trends in transglutaminase technology for food processing. Review. Food Sci Technol Res 6: 151-160.

5. Mo H, Kariluoto S, Piironen V, Zhu Y, Mark G, et al. (2013) Effect of soybean processing on content and bioaccessibility of folate, vitamin B12 and isoflavones in tofu and tempe. Food Chem 141: 2418-2425.

6. Abd Karim A, Sulebele GA, Azhar ME, Ping CY (1999) Effect of carrageenan on yield and properties of tofu. Food Chemistry 66: 159-165.

7. Wang L, Saito M, Tatsumi E, LI L (2003) Antioxidative and angiotensin I-converting enzyme inhibitory activities of sufu (fermented tofu) extracts. Japan Agricultural Research Quarterly 37: 129-132.

8. de Man JM, de Man L, Gupta S (1986) Texture and microstructure of soyabean curd (tofu) as affected by deficient coagulants. Food Microstructure 5: 83-89.

9. Oboh G, Omotosho OE (2005) Effect of types of coagulant on the nutritive value and in vitro of coagulant on the nutritive value and in vitro multi-enzyme protein digestibility of tofu. J Food Technology 3: 182-187.

10. https://data.nal.usda.gov/dataset/composition-foods-raw-processed-prepared-usda-national-nutrient-database-standard-reference-release-28-0

11. El Owni OAO, Hamid OIA (2007) Production of white cheese (Gibna bayda) in Zalingei area West Darfur (Sudan). Australian J of Basic and Applied Science 1: 756-762.

12. Elkhider IAE, El Zubeir IEM, Basheir AA (2012) The impact of processing methods on the quality of Sudanese white cheese produced by small scale in New Halfa area. Acta Agriculturae Slovenica 100: 131-137.

13. Mohamed OAE, El Zubeir IEM (2018) Comparative study on chemical and microbiological properties of white cheese produced in traditional and modern factories. Annals of Food Science and Technology 19: 111-120.

14. Elkhider IAE, El Zubeir IEM, Basheir AA, Fadlelmoula AA (2011) Composition and hygienic quality of Sudanese white cheese produced by small scale in rural area of eastern Sudan. Annals of Food Science and Technology 12: 186-192.

15. Lim TB, DeMan MJ, Deman L, Buzzell IR (1990) Yield and quality of Tofu as affected by soybeans and soymilk characteristics calcium sulfate coagulant. J Food Sciences 55: 1088-1093.

16. AOAC (2000) Official Methods of Analysis of AOAC International, $17^{\text {th }}$ Edn. AOAC International Gaitherburg, MD, USA

17. Shokumbi OS, Babajide OO, Otaigbe, DO, Tayo GO (2011) Effect of coagulants on the yield nutrient and anti-nutrient composition of tofu. Archives of Applied Science Research 3: 522-527.
18. Mustafa WA, Sulieman AE, Abdelgadir WS, Elkhalifa EA (2013) Chemical composition of the white cheese produced at household level in Dueim area, White Nile State, Sudan. J Food Nutr Disor 2: 2-5.

19. SSMO (2002) Sudanese Standards and Meteorology Organization. White Soft Cheese: Standard Number 1428.

20. Shuiep ES, Eltaher HA, El Zubeir IEM (2016) Effect of stage of lactation and order of parity on milk composition and daily milk yield among local and crossbred cows in South Darfur State, Sudan. Sudan Journal of Agricultural and Veterinary Sciences 17: 86-99.

21. Nour El Diam MSA, El Zubeir IEM (2010) Chemical composition of processed cheese using Sudanese white cheese. Research Journal of Animal and Veterinary Sciences 5: 31-37.

22. Suliman AHY, Abdalla MI, El Zubeir IEM (2013) Effect of level of milk fat on the compositional quality of Sudanese white cheese during storage. Sky Journal of Food Science 2: 1-9.

23. Ndatsu Y, Olekan AA (2012) Effects of different types of coagulants on the nutritional quality tofu produced in the Northern part of Nigeria. World $\mathrm{J}$ Dairy \& Food Sci 7: 135-141.

24. Warsama LM, El Zubier IEM, El Owni OAO (2006) Composition and hygienic quality of Sudanese white soft cheese in Khartoum North markets (Sudan). International Journal of Dairy Science 1: 36-43.

25. Suliman AHY, Abdalla MI, El Zubeir IEM (2019) Effect of milk fat level on salt, some mineral content and sensory characteristic of Sudanese white cheese during storage. J Dairy Research and Technology 2: 008.

26. Hamid OIA, El Owni OAO, Musa TM (2008) Effect of salt concentration on weight loss chemical composition and sensory characteristics of Sudanese white cheese. Int J of Dairy Science 3: 79-85.

27. Abdalla MOM, Ahmed OI (2010) Effect of heat treatment, level of sodium chloride, calcium chloride on the chemical composition of white cheese. Research Journal of Animal and Veterinary Sciences 5: 69-72.

28. Shih MC, Yang KT, Ksuo SJ (2002) Quality and antioxidative activity of black soybean tofu as affected by bean cultivar. Journal of Food Science 67: 480-484.

29. El Owni OAO, Hamid OI (2008) Effect of storage period on weight loss, chemical composition, microbiological and sensory characteristics of $\mathrm{Su}-$ danese white cheese (Gibna bayda). Pakistan Journal of Nutrition 7: 7580 .

30. Hayalogou AA, Guven M, Fox PF, McSweeny PH (2005) Influence of starters on chemical, biochemical and sensory changes in Trukish white brined cheese during ripening. J Dairy Science 88: 3460-3474.

31. Abdalla MOM, Mohamed SN (2009) Effect of storage period on chemical composition and sensory characteristics of vacuum packaged white soft cheese. Pakistan Journal of Nutrition 8: 145-147.

32. Tarakci Z, Kucukoner E (2006) Changes on physicochemical, lipolysis and proteolysis of vacuum packed Turkish Kasar cheese during ripening. J Central European Agri 7: 459-464.

33. El Owni OAO, Hamid OI (2009) Effect of storage temperature on weight loss, chemical composition microbiological properties and sensory characteristics of Sudanese white cheese (Gibna Byda). Res J Agric Biol Sci 5: 498-505.

34. Abdalla MI, El Zubeir IEM, Hassan FA (2013) Effect of packaging technique in physicochemical composition of Sudanese white soft cheese. International Journal of Scientific and Research Publications 3: 1-8.

35. El Zubeir IEM, Abdalla MI, Ahmed AR, Mohamed BE (2014) Effect of storage period and packaging type on ripening indices of Sudanese white cheese. Frontiers in Food Science and Technology 1: 1-6. 
Citation: Elmahi AKH, Ibtisam EM El Zubeir (2020) Physicochemical, Sensory Characteristics and Cost of Production of Soy milk Cheese, Sudanese White Cheese and Their Mixture During Storage. J Protein Res Bioinform 2: 007.

- Page 7 of 8 •

36. Birghila S, Dobrinas S, Stanciu G, Soceanu A (2008) Determination of major and minor elements in milk through ICP-AES. Environmental Engineering and Management Journal 7: 805-808.

37. Parbhakaran MP, Perera CO, Valiyaveettil S (2006) Effect of different coagulants on the isoflavone level and physical properties of prepared firm tofu. Food Chemistry 99: 492-499

38. Blessing IA, Gregory IO (2010) Effect of processing on the proximate composition of the dehulle and undulled mungbean flours. Pakistan Journal of Nutrition 9: 1006-1016.

39. Obatolu VA (2008) Effect of different coagulants on yield and quality of tofu from soymilk. Eur Food Res Technol 226: 467-472.

40. Jyoti Parma, Shama HR, Ranjana Verma (2007) Effect of source and coagulants on the Physicochemical and organoleptic evaluation of soy tofu Dairying. Food and HS 26: 69-74.

41. Liu K (1997) Soybeans: Chemistry, Technology, and Utilization. Springer ISBN 978-0-8342-1299-2.

42. Farah NAM, El Zubeir IEM (2019) Comparison on the acceptability of mudaffara cheese using black cumin and sesame seeds during storage. Annals of Food Science and Technology 20: 721-727.
43. Hamid OIA, El Owni OAO (2008) Processing and properties of Sudanese white cheese (Gibna bayda) in small-scale cheese units in South and West Darfur States (Sudan). Livestock Research for Rural Development 20

44. Nour El Diam MSA, El Zubeir IEM (2007) Yield and sensory evaluation of the processed cheese from Sudanese white cheese. Research Journal of Animal and Veterinary Sciences 2: 47-52.

45. Nonaka M, Matsuura Y, Motoki M (1996) Incorporation of lysine dipeptides into ot,1-casein by $\mathrm{Ca} 2+$ independent microbial transglutaminase. Biosci Biotechnol Biochem 60: 131-133.

46. Guo S, Ono T (2005) The Role of composition and content of protein particles in soymilk on tofu curdling by glucono- and lactone or calcium sulfate. Journal of Food Science 70: 258-262.

47. Ojha P, Karki TB, Maharjan S (2014) Effect of sprouting in physico-chemical properties of Tofu. J Nutr Health Food Eng 1: 1-8. 


\section{di \\ Hetario}

Advances In Industrial Biotechnology | ISSN: 2639-5665

Advances In Microbiology Research | ISSN: 2689-694X

Archives Of Surgery And Surgical Education | ISSN: 2689-3126

Archives Of Urology

Archives Of Zoological Studies | ISSN: 2640-7779

Current Trends Medical And Biological Engineering

International Journal Of Case Reports And Therapeutic Studies | ISSN: 2689-310X

Journal Of Addiction \& Addictive Disorders | ISSN: 2578-7276

Journal Of Agronomy \& Agricultural Science | ISSN: 2689-8292

Journal Of AIDS Clinical Research \& STDs | ISSN: 2572-7370

Journal Of Alcoholism Drug Abuse \& Substance Dependence | ISSN: 2572-9594

Journal Of Allergy Disorders \& Therapy | ISSN: 2470-749X

Journal Of Alternative Complementary \& Integrative Medicine | ISSN: 2470-7562

Journal Of Alzheimers \& Neurodegenerative Diseases | ISSN: 2572-9608

Journal Of Anesthesia \& Clinical Care | ISSN: 2378-8879

Journal Of Angiology \& Vascular Surgery | ISSN: 2572-7397

Journal Of Animal Research \& Veterinary Science | ISSN: 2639-3751

Journal Of Aquaculture \& Fisheries | ISSN: 2576-5523

Journal Of Atmospheric \& Earth Sciences | ISSN: 2689-8780

Journal Of Biotech Research \& Biochemistry

Journal Of Brain \& Neuroscience Research

Journal Of Cancer Biology \& Treatment | ISSN: 2470-7546

Journal Of Cardiology Study \& Research | ISSN: 2640-768X

Journal Of Cell Biology \& Cell Metabolism | ISSN: 2381-1943

Journal Of Clinical Dermatology \& Therapy | ISSN: 2378-8771

Journal Of Clinical Immunology \& Immunotherapy | ISSN: 2378-8844

Journal Of Clinical Studies \& Medical Case Reports | ISSN: 2378-8801

Journal Of Community Medicine \& Public Health Care | ISSN: 2381-1978

Journal Of Cytology \& Tissue Biology | ISSN: 2378-9107

Journal Of Dairy Research \& Technology | ISSN: 2688-9315

Journal Of Dentistry Oral Health \& Cosmesis | ISSN: 2473-6783

Journal Of Diabetes \& Metabolic Disorders | ISSN: 2381-201X

Journal Of Emergency Medicine Trauma \& Surgical Care | ISSN: 2378-8798

Journal Of Environmental Science Current Research | ISSN: 2643-5020

Journal Of Food Science \& Nutrition | ISSN: 2470-1076

Journal Of Forensic Legal \& Investigative Sciences | ISSN: 2473-733X

Journal Of Gastroenterology \& Hepatology Research | ISSN: 2574-2566
Journal Of Genetics \& Genomic Sciences | ISSN: 2574-2485

Journal Of Gerontology \& Geriatric Medicine | ISSN: 2381-8662

Journal Of Hematology Blood Transfusion \& Disorders | ISSN: 2572-2999

Journal Of Hospice \& Palliative Medical Care

Journal Of Human Endocrinology | ISSN: 2572-9640

Journal Of Infectious \& Non Infectious Diseases | ISSN: 2381-8654

Journal Of Internal Medicine \& Primary Healthcare | ISSN: 2574-2493

Journal Of Light \& Laser Current Trends

Journal Of Medicine Study \& Research | ISSN: 2639-5657

Journal Of Modern Chemical Sciences

Journal Of Nanotechnology Nanomedicine \& Nanobiotechnology | ISSN: 2381-2044

Journal Of Neonatology \& Clinical Pediatrics | ISSN: 2378-878X

Journal Of Nephrology \& Renal Therapy | ISSN: 2473-7313

Journal Of Non Invasive Vascular Investigation | ISSN: 2572-7400

Journal Of Nuclear Medicine Radiology \& Radiation Therapy | ISSN: 2572-7419

Journal Of Obesity \& Weight Loss | ISSN: 2473-7372

Journal Of Ophthalmology \& Clinical Research | ISSN: 2378-8887

Journal Of Orthopedic Research \& Physiotherapy | ISSN: 2381-2052

Journal Of Otolaryngology Head \& Neck Surgery | ISSN: 2573-010X

Journal Of Pathology Clinical \& Medical Research

Journal Of Pharmacology Pharmaceutics \& Pharmacovigilance | ISSN: 2639-5649

Journal Of Physical Medicine Rehabilitation \& Disabilities | ISSN: 2381-8670

Journal Of Plant Science Current Research | ISSN: 2639-3743

Journal Of Practical \& Professional Nursing | ISSN: 2639-5681

Journal Of Protein Research \& Bioinformatics

Journal Of Psychiatry Depression \& Anxiety | ISSN: 2573-0150

Journal Of Pulmonary Medicine \& Respiratory Research | ISSN: 2573-0177

Journal Of Reproductive Medicine Gynaecology \& Obstetrics | ISSN: 2574-2574

Journal Of Stem Cells Research Development \& Therapy | ISSN: 2381-2060

Journal Of Surgery Current Trends \& Innovations | ISSN: 2578-7284

Journal Of Toxicology Current Research | ISSN: 2639-3735

Journal Of Translational Science And Research

Journal Of Vaccines Research \& Vaccination | ISSN: 2573-0193

Journal Of Virology \& Antivirals

Sports Medicine And Injury Care Journal | ISSN: 2689-8829

Trends In Anatomy \& Physiology | ISSN: 2640-7752

Submit Your Manuscript: https://www.heraldopenaccess.us/submit-manuscript 